Acta vet. scand. 1988, 29, 101-107.

From Novo AS, Denmark and the Department of Cattle and Sheep Diseases, Swedish University of Agricultural Sciences, Uppsala, Sweden.

\title{
Improvement of the Local Tolerance of a Potassium Penicillin G Formulation for Injection
}

\author{
By Vivi Dall and Jan Luthman
}

\begin{abstract}
Dall, V. and J. Luthman: Improvement of the local tolerance of a potassium pencillin $G$ formulation for injection. Acta vet. scand. 1988, 29, 101-107. - The damaging effect at the injection site (muscle) of a series of different preparations of penicillin $\mathrm{C}$ with increasing content of citrate buffer has been investigated in rabbits in order to improve the local tolerance of the drug preparation. The injections were given in M.sacrospinalis and 3 days after injection the animals were sacrified and the areas of necrotic muscle tissue were isolated and weighed. The damage from the different preparations was determined on the basis of these weighing results. It was concluded that Novocillin $3.15 \mathrm{~g}$ and $6.3 \mathrm{~g}$ in $20 \mathrm{ml}$ aqueous solution could be improved by adding $3 x$ the original content of citrate buffer to the preparation resulting in a $38 \%$ decrease of the mean weight of necrotic areas at the injection site. Moreover, it was shown that the mean weight of necrotic areas at the injection site was diminished by $41 \%$ when injecting the improved $6.3 \mathrm{~g}$ concentration in a volume of $0.1 \mathrm{ml}$ compared to injecting the improved $3.15 \mathrm{~g}$ concentration in a volume of $0.2 \mathrm{ml}$, which provides the same dose of penicillin G.
\end{abstract}

citrate buffer; necrosis; rabbits.

\section{Introduction}

In veterinary medicine antibiotics are often administered intramuscularly. Intramuscular injections may cause damage by distension and disruption of the tissue, especially when large volumes are injected. Of major importance is however that some antibiotics possess a strong irritating effect, which often is the main cause to the observed damage. The local toxicity of selected antibiotics and some frequently used vehicles was studied by Rasmussen \& Hogh (1971), Rasmussen \& Svendsen (1976) and Svendsen (1972). The local irritating effect of penicillins was found to be small, while tetracyclines caused severe local reactions described as necrosis, hemorrhages and fibrosis. Similar reactions after injection of oxytetracycline was described by Immelman et al. (1978).
Novocillin vet. (injectable potassium penicillin G) was introduced at a time when the local muscle damage caused by intramuscular drug preparations did not receive much attention. In a preliminary pharmacokinetic study in cows and pigs receiving high doses twice daily for 5 days the muscle damage observed at the injection site was considered unacceptable for todays's requirement. The present studies in rabbits were performed with the aim to minimize the local damaging effect of the preparation.

\section{Material and methods \\ The rabbit model}

Young New Zealand White rabbits of either sexes, weight $2.5-3 \mathrm{~kg}$, were used. They were housed individually in cages and were trained to be familiar with the handling proce- 
dures during the last 14 days before the start of the study.

For each study the animals were divided randomly with respect to weight into groups of 4 , one group for each test preparation. The skin on the back was shaved $24 \mathrm{~h}$ before the injection. Each animal recieved one single intramuscular injection of $0.2 \mathrm{ml}$ of the actual preparation. The injection was given by using a disposable syringe of $1 \mathrm{ml}$ and a needle, B-DR $26 \mathrm{G} \mathrm{3/8}(0.45 \cdot 10 \mathrm{~mm})$, inserted centrally into the right M.sacrospinalis about $20 \mathrm{~mm}$ from the central spinal line and $2 / 3$ of the distance from the crest of ileum to the last rib. This corresponds to the broadest part of the rabbit when it is placed on the ventral part of the body with the hind legs drawn downward-outside the table and fixed by an assistant with one hand on the neck and the other on the loin. With fixed cutis the needle was inserted perpendicularly to the surface. After injection the neddle was withdrawn avoiding pressure or massage.

Three days after the injection the rabbits were anaesthetized with $50 \mathrm{mg} / \mathrm{kg}$ of pentobarbiturate intravenously and killed by exsanguination. The injected muscle was isolated using dissection and the injection site localized over a light cabinet. Macroscopic damages were examined by slicing the muscle. Areas of necrotic muscle tissue were isolated by careful separation from surrounding tissue and weighed.

\section{Preparations}

1. Inj. Novocillin $3.15 \mathrm{~g}$ (potassium bensylpenicillin $3.15 \mathrm{~g}$, sodium citr.dibasic $18 \mathrm{mg}$, sodium citrate $95 \mathrm{mg}$ ) dissolved in $18 \mathrm{ml}$ of sterile water giving a solution of $20 \mathrm{ml}$.

2-7. Preparation 1 added 50\%, $100 \%$, $200 \%, 300 \%, 400 \%$ and $600 \%$ more of its original content of citrate buffer.
8. Inj. Novocillin $6.3 \mathrm{~g}$ (potassium bensylpenicillin $6.3 \mathrm{~g}$, sodium citr.dibasic 36 $\mathrm{mg}$, sodium citrate $190 \mathrm{mg}$ ) dissolved in $18 \mathrm{ml}$ of sterile water giving a solution of $22 \mathrm{ml}$.

9. Preparation 8 added $300 \%$ more of its original content of citrate buffer.

10. Inj. Novocillin $6.3 \mathrm{~g}$ dissolved in $16 \mathrm{ml}$ of sterile water giving a solution of 20 $\mathrm{ml}$.

11. Preparation 10 added $300 \%$ more of its original content of citrate buffer.

\section{Experiments}

A series of experiments were performed with the following aims:

Exp. 1.: To compare the local irritating effect of Novocillin $3.15 \mathrm{~g}$ and each of its components diluted to the same concentrations as they were found in the original preparation.

Exp. 2.: To compare the effects of Novocillin 3.15 and $6.3 \mathrm{~g}$. Both preparations were diluted in $18 \mathrm{ml}$ of sterile water.

Exp. 3-5.: To compare the effect of Novocillin $3.15 \mathrm{~g}$ diluted in $18 \mathrm{ml}$ of sterile water and added increasing amounts of its citrate buffer content (preparations 2-7).

Exp. 6.: To compare the effect of Novocillin $3.15 \mathrm{~g}$ and $6.3 \mathrm{~g}$ (the original preparations) and the same preparations added $3 x$ the original citrate buffer content (the improved preparation). All preparations were dissolved in $18 \mathrm{ml}$ of water.

A study of the effect of the improved $6.3 \mathrm{~g}$ preparation dissolved in $16 \mathrm{ml}$ of water was also included.

Exp. 7.: To compare the effects of the improved 3.15 and $6.3 \mathrm{~g}$ preparations dissolved in $18 \mathrm{ml}$ of water.

The ANOVA 1 test and Tukey's test were used for the statistical evaluations. 
Table 1. Mean weights and range of necrotic muscle tissue at the injection site 3 days after i.m. injection of $0.2 \mathrm{ml}$ of Novocillin and its content of penicillin $G$ and citrate buffer (the same concentration as in the Novocillin preparations) into rabbits.

\begin{tabular}{lc}
\hline Preparation & $\begin{array}{c}\text { Weight (g) of isolated necrotic } \\
\text { muscle tissue (Mean and range) }\end{array}$ \\
\hline $\begin{array}{l}\text { Inj. Novocillin vet } \\
3.15 \mathrm{~g} \text { dissolved in } \\
18 \mathrm{ml} \text { of sterile water }\end{array}$ & 0.829 \\
$\begin{array}{l}\text { Penicillin G } \\
\text { (Concentration as in the }\end{array}$ & $(0.585-1.160)$ \\
$\begin{array}{l}\text { Novocillin preparation) } \\
\text { Citrate buffer } \\
\text { (Concentration as in the } \\
\text { Novocillin preparation) }\end{array}$ & 0.953 \\
\hline
\end{tabular}

\section{Results}

The results of the experiments are summarized in Tables 1-5. Injection of Novocillin $3.15 \mathrm{~g}$ dissolved in $18 \mathrm{ml}$ of sterile water caused damage at the injection site as shown by the presence of a large and well-defined necrotic area. From the results shown in Table 1 it seems clear that penicillin $G$ caused the muscle necrosis as there were only small differences in weight between the necrosis caused by penicillin $G$ and the Novocillin preparation.

The results shown in Table 2 indicate that the concentration of penicillin solution is of importance for the development of the tissue damage, as the weight of the necrotic tissue was higher after $6.3 \mathrm{~g}$ Novocillin than after the $3.15 \mathrm{~g}$ preparation. The difference in weight was $39 \%$.

As shown in Tables 3-6 the weight of the necrotic tissue was reduced by increasing amounts of citrate buffer. When the effect of the original Novocillin $3.15 \mathrm{~g}$ was compared with a preparation added 3 times more citrate buffer, the difference in weight between the necrotic tissues was statistically significant $(\mathrm{p}<0.05)$. The difference in weight was $45 \%$ (Table 3 ).

Table 2. Mean weights and range of necrotic tissue at the injection site 3 days after i.m. injection of $0.2 \mathrm{ml}$ of Inj. Novocillin vet. $3.15 \mathrm{~g}$ and $6.3 \mathrm{~g}$ (both dissolved in $18 \mathrm{ml}$ of sterile water) into rabbits.

\begin{tabular}{lc}
\hline Preparation & $\begin{array}{c}\text { Weight (g) of isolated necrotic } \\
\text { muscle tissue (Mean and range) }\end{array}$ \\
\hline $\begin{array}{l}\text { Inj. Novocillin vet } \\
3.15 \mathrm{~g} \text { dissolved in }\end{array}$ & 0.801 \\
$18 \mathrm{ml}$ of sterile water & $(0.556-1.093)$ \\
Inj. Nocovillin vet & \\
$6.3 \mathrm{~g}$ dissolved in & 1.115 \\
$18 \mathrm{ml}$ of sterile water & $(0.765-1.137)$ \\
\hline
\end{tabular}


Table 3. Mean weights and range of necrotic tissue at the injection site 3 days after i.m. injection of $0.2 \mathrm{ml}$ of different Novocillin preparation into rabbits.

\begin{tabular}{|c|c|c|c|}
\hline \multirow[t]{2}{*}{ Preparation } & \multicolumn{3}{|c|}{$\begin{array}{l}\text { Weight (g) isolated necrotic muscle tissue } \\
\text { (Mean and range) }\end{array}$} \\
\hline & Experiment 3 & Experiment 4 & Experiment 5 \\
\hline $\begin{array}{l}\text { Novocillin } 3.15 \mathrm{~g} \\
\text { in } 18 \mathrm{ml} \text { of sterile } \\
\text { water (1) }\end{array}$ & & $\begin{array}{c}0.881 \\
(0.404-1.139)\end{array}$ & $\begin{array}{c}0.838 \\
(0.518-1.072)\end{array}$ \\
\hline $\begin{array}{l}\text { (1) added } 50 \% \\
\text { more of citrate } \\
\text { buffer }\end{array}$ & $\begin{array}{c}0.875 \\
(0.731-0.996)\end{array}$ & & \\
\hline $\begin{array}{l}\text { (1) added } 100 \% \\
\text { more of citrate } \\
\text { buffer }\end{array}$ & $\begin{array}{c}0.814 \\
(0.632-0.895)\end{array}$ & & \\
\hline $\begin{array}{l}\text { (1) added } 200 \% \\
\text { more of citrate } \\
\text { buffer }\end{array}$ & $\begin{array}{c}0.679 \\
(0.656-0.704)\end{array}$ & $\begin{array}{c}0.597 \\
(0.336-0.739)\end{array}$ & $\begin{array}{c}0.669 \\
(0.449-0.835)\end{array}$ \\
\hline $\begin{array}{l}\text { (1) added } 300 \% \\
\text { more of citrate } \\
\text { buffer }\end{array}$ & . & & $\begin{array}{c}0.461^{*} \\
(0.405-0.543)\end{array}$ \\
\hline $\begin{array}{l}\text { (1) added } 400 \% \\
\text { more of citrate } \\
\text { buffer }\end{array}$ & & $\begin{array}{c}0.420 \\
(0.206-0.533)\end{array}$ & $\begin{array}{c}0.486 \\
(0.285-0.628)\end{array}$ \\
\hline $\begin{array}{l}\text { (1) added } 600 \% \\
\text { more of citrate } \\
\text { buffer }\end{array}$ & & $\begin{array}{c}0.393 \\
(0.255-0.588)\end{array}$ & \\
\hline
\end{tabular}

*Significantly different from the original preparation (ANOVA 1 and Tukey's test. $\mathrm{p}<0.05$ ).

Similar results were obtained in Experiment 6 (Table 4). In this experiment the reduction was $38 \%$. Also this difference was statistically significant $(\mathrm{p}<0.05)$. As shown in Table 4 the tissue irritating effect of the $6.3 \mathrm{~g}$ Novocillin preparation was also significantly reduced $(\mathrm{p}<0.05$ ) when 3 times more citrate buffer was added. No difference was observed when the improved $6.3 \mathrm{~g}$ preparation was dissolved in 16 and $18 \mathrm{ml}$ of sterile water. From Table 5 it can be seen that also the injected volume is of importance for the severity of the tissue damage. Injection of
$0.2 \mathrm{ml}$ of the improved $3.15 \mathrm{~g}$ Novocillin preparation caused a more severe necrosis than $0.1 \mathrm{ml}$ of the improved $6.3 \mathrm{~g}$ preparation.

\section{Discussion}

A number of different techniques have been used for the study of local toxicity of drug preparations intended for intramuscular injection (Rasmussen \& Høgh 1971, Rasmussen \& Svendsen 1976, Svendsen et al. 1979, Steiness et al. 1978). In the present study the rabbits were killed for necropsy 3 days after the injections, when, as described by Svend- 
Table 4. Mean weights and range of necrotic tissue at the injection site 3 days after i.m. injection of $0.2 \mathrm{ml}$ of different Novocillin preparations into rabbits.

\begin{tabular}{lc}
\hline Preparation & $\begin{array}{c}\text { Weight (g) of isolated necrotic } \\
\text { muscle tissue (Mean and range) }\end{array}$ \\
\hline $\begin{array}{l}\text { Novocillin } 3.15 \mathrm{~g} \text { in } \\
18 \mathrm{ml} \text { of sterile water (1) }\end{array}$ & 0.845 \\
$\begin{array}{l}\text { (1) added } 300 \% \text { more } \\
\text { of citrate buffer }\end{array}$ & $0.780-0.909)$ \\
$\begin{array}{l}\text { Novocillin } 6.3 \mathrm{~g} \text { in } \\
18 \mathrm{ml} \text { of sterile water (2) }\end{array}$ & $(0.457-0.674)$ \\
(2) added 300\% more & 1.158 \\
$\quad$ of citrate buffer & $(1.054-1.239)$ \\
(2) added 300\% more \\
of citrate buffer and \\
dissolved in $16 \mathrm{ml}$ of \\
sterile water
\end{tabular}

Table 5. Mean weights and range of necrotic tissue at the injection site after i.m. injection of different volumes of Novocillin into rabbits.

\begin{tabular}{|c|c|}
\hline Preparation & $\begin{array}{l}\text { Weight ( } \mathrm{g} \text { ) of isolated necrotic } \\
\text { muscle tissue (Mean and range) }\end{array}$ \\
\hline $\begin{array}{l}\text { Inj. Novocillin } 3.15 \mathrm{~g} \\
\text { added } 300 \% \text { more of } \\
\text { citrate buffer } \\
\quad 0.2 \mathrm{ml}\end{array}$ & $\begin{array}{c}0.308 \\
(0.151-0.437)\end{array}$ \\
\hline $\begin{array}{l}\text { Inj. Novocillin } 6.3 \mathrm{~g} \\
\text { added } 300 \% \text { more of } \\
\text { citrate buffer } \\
\quad 0.1 \mathrm{ml}\end{array}$ & $\begin{array}{c}0.182 \\
(0.133-0.224)\end{array}$ \\
\hline $\begin{array}{l}\text { Inj. Novocillin } 6.3 \mathrm{~g} \\
\text { added } 300 \% \text { more of } \\
\text { citrate buffer } \\
\quad 0.2 \mathrm{ml}\end{array}$ & $\begin{array}{c}0.491 \\
(0.367-0.592)\end{array}$ \\
\hline
\end{tabular}

sen (1983), the muscle lesions could be expected to be at their maxima and also easy to dissect. Microscopic examination of the muscle tissue was not included. All tested preparations caused a type of muscle necrosis which was easily identified by its abnormal colour and a greyish demarcating zone.
Weighing of the dissected necrotic muscle tissue was therefore a reliable measure of the damaging effect. It was previously stated that only minimal histological alterations occur if macroscopic changes are not found (Rasmussen \& Svendsen 1976). The values given in the tables are mean and range. By 
comparing the results from the various experiments the reproducibility of this simple method must be considered as remarkable. It seems clear from the results shown Table 1 that the local toxicity of Novocillin was due to the penicillin $\mathrm{G}$ component, since the citrate buffer showed a minimal damaging effect at the injection site. The tendency to a lesser local effect of Novocillin compared to penicillin $\mathrm{G}$ gave support to a theory that the citrate buffer may reduce the penicillin G-induced necrosis.

From Experiment 2 (Table 2) it was expected that Novocillin $6.3 \mathrm{~g}$ would give rise to a necrosis with a weight twice that induced by the $3.15 \mathrm{~g}$ preparation when the same volume of the preparations was injected. As shown in the table the difference in weight was only $39 \%$. The unexpected small difference may be due to the fact that the amount of citrate buffer $/ \mathrm{ml}$ was doubled in the $6.3 \mathrm{~g}$ preparation. Thus these results also favoured the hypothesis that citrate buffer may possess a protecting effect.

The results given in Table 3 show that the weight of the necrotic tissue could be reduced by addition of increasing amounts of the citrate buffer until 3 times the original content was added. This preparation caused significantly less damage compared to the original preparation. By increasing the amount of citrate buffer further, the advantage was questionable.

The results from the preceeding experiment were verified in Experiment 6 (Table 4). As seen from the table the local toxicity of both the $3.15 \mathrm{~g}$ and the $6.3 \mathrm{~g}$ Novocillin preparations was reduced significantly when 3 times more citrate was added. No difference was recorded when the improved $6.3 \mathrm{~g}$ preparation was dissolved in 16 and $18 \mathrm{ml}$.

The role of the injected volume for the local toxicity is demonstrated in Table 5. The injection of $0.1 \mathrm{ml}$ of the improved $6.3 \mathrm{~g}$ pre- paration caused significantly less damage than $0.2 \mathrm{ml}$ of the improved $3.15 \mathrm{~g}$ preparation. The difference in weight of the damaged tissue was $170 \%$ although the same amount of penicillin $G$ was injected. It was concluded earlier (Table 2) that the amount of penicillin $\mathrm{G}$ was of importance, but at the levels used in the present experiments the volume is a major factor.

The present series of experiments demonstrate that citrate buffer exerts a favourable effect on the local irritating properties of penicillin $\mathrm{G}$. The explanation may be that the anticoagulating effect of the citrate buffer results in an improved microcirculation at the injection site. This hypothesis may be further tested by using a heparin-containing test preparation.

\section{Acknowledgements}

The preparations investigated were prepared by Jonna Hindkaer Dahl, Novo. The authors wish to thank Gitte Clifford Jensen for her excellent technical assistance.

\section{References}

Immelman A, Botha WS, Gribb D: Muscle irritation caused by different products containing oxytetracycline. J. South Afr. vet. Assoc. 1978, 49, 103-105.

Rasmussen F, Høgh P: Lokalirritation og koncentrationer på injektionsstedet efter intramuskulær injektion af antibiotikaholdige præparater på køer og grise. (Irritating effect and concentrations at the injection site after intramuscular injection of antibiotic preparations in cows and pigs). Nord. Vet. Med. 1971, 23, 593-605.

Rasmussen $F$, Svendsen $O$ : Tissue damage and concentration at the injection site after intramuscular injection of chemotherapeutics and vehicles in pigs. Res. Vet. Sci. 1976, 20, 55-60.

Steiness $E$, Rasmussen $F$, Svendsen $O$, Nielsen P: A comparative study of serum creatine phosphokinase (CPK) activity in rabbits, pigs and humans after intramuscular injection of local damaging drugs. Acta pharmacol. toxicol. 1978, 42, 357364. 
Svendsen $O$ : Histologiske forandringer efter intramuskulære injektioner med antibiotikaholdige præparater (Histologic changes after intramuscular injections with antibiotic preparations). Nord. Vet. Med. 1972, 24, 181-185.

Svendsen $O$ : Local muscle damage and oily vehicles: A study of local reaction in rabbits after intramuscular injection of neuroleptic drugs in aqueous or oily vehicles. Acta pharmacol. toxicol. 1983, 52, 298-304.

Svendsen $O$, Rasmussen $F$, Nielsen $P$, Steiness $E$ : The loss of creatine phosphokinase (CK) from intramuscular injection sites in rabbits. A predictive tool for local toxicity. Acta pharmacol. toxicol. 1979, 44, 324-328.

\section{Sammanfattning}

Förbättring av den lokala toleransen av en Penicillin G-beredning för injektion.

Den vävnadsirriterande effekten av en serie penicillin $\mathrm{G}$ formuleringar innehăllande stigande mängder av citrat buffer studerades hos kanin. Infektionerna gavs i M.sacrospinalis. Kaninerna avlivades efter 3 dagar och skadade muskelpartier isolerades och vägdes. Det visades att den lokala toleransen hos Novocillin $3.15 \mathrm{~g}$ och $6.3 \mathrm{~g}$ kunde förbättras signifikant om innehảllet av citrat buffer ökades $300 \%$. Den förbättrade formuleringen resulterade i en 38\%-ig reduktion av vävnadsskadorna. Det visades också att $0.1 \mathrm{ml}$ av den förbättrade $6.3 \mathrm{~g}$ formuleringen gav $41 \%$ mindre vävnadsskador än $0.2 \mathrm{ml}$ av motsvarande $3.15 \mathrm{~g}$ formulering.

(Received September 2, 1987).

Reprints may be requested from: Gustav Pedersen, Novo Agro-Vet., Rygaards Allé 131, DK-2900 Hellerup, Denmark. 
